\title{
[The Terminal Kaleidoscope: Edward Ka-Spel's Poetry in the Age of Postmodernity ]
}

\section{Radek Glabazňa}

Silesian University, Opava

[Abstract] The paper studies the poetry of the British experimental musician and poet/lyricist Edward $\mathrm{Ka}$-Spel. Its main objective is to relate Ka-spel's writing to the theories of the postmodern, both in the aesthetic sense of postmodernism as well as in the philosophical-ideological sense of postmodernity. The article also maintains throughout that Ka-spel continues to write in the lineage of high modernism and can therefore be considered a genuine exponent of the avant-garde. While the first part of the paper interrogates the theoretical implications of Ka-spel's relationship with the postmodern, the second, more practical part turns to close reading as the main tool for exploring the complexities and intricacies of Ka-spel's poetic imagery.

[Keywords] postmodernity; postmodernism; fragmentation; repetition; dystopia; unity 
It has been argued by postmodern theorists on several occasions that in the present age, marked by an acute feeling of the end of history, including the history of art, there is no room left for authentic experimentation or innovation, because everything has simply already been done. The French guru of postmodern theory, Jean Baudrillard, stated that "all that are left are pieces. All that remains to be done is to play with the pieces. Playing with the pieces - that is postmodern" (Baudrillard 25). Similarly, though arguing from an entirely different philosophical and ideological perspective, the American Marxist theorist Fredric Jameson writes:

The writers and artists of the present day will no longer be able to invent new styles and words - they've already been invented; only a limited number of combinations are possible; the unique ones have been thought of already... In a world in which stylistic innovation is no longer possible, all that is left is to imitate dead styles, to speak through the masks and the voices of the styles in the imaginary museum. (168-9)

However, these pessimistic, end-of-history views of the artistic possibilities of the present day have been at least partly disproved by some great works of art that the postmodern era has spawned. Although the pastiche-like character of many of these works fits in with Baudrillard's notion of "playing with the pieces", they also disprove Baudrillard in their ability to still produce and transmit substantial meaning, of which the French theorist believed our days are utterly devoid. The area of poetic experimentation is a fruitful field to prove this point. Although the days of unique experiments carried out by various avant-garde movements of high modernism are probably gone, the possibilities of combination and interplay seem to be inexhaustible, and they can give rise to complex and valuable writings.

The British artist Edward Ka-Spel, arguably the most prolific musician and lyricist alive, has now been negotiating the promises and contradictions of the postmodern for nearly forty years - as the frontman of the Anglo-Dutch band The Legendary Pink Dots, often dubbed the kings of imaginative music, or as a solo artist. His haunting lyrics hail from the indefinite interstices between discovery and loss, memory and amnesia, painful immanence and liberating transcendence. Both musically and lyrically, he is relentlessly experimental; his art is informed by the "postmodern condition", defined by another French postmodernist par excellence, Jean François Lyotard, as follows:

It is] the condition of the literatures and arts that have no assigned addressee and no regulating ideal, yet in which value is regularly measured on the stock of experimentation. Or, to put dramatically, in which it is measured by the distortion that is inflicted upon the materials, the forms and the structures of sensibility and thought. (16)

Ka-Spel's music and lyrics indeed inflict a lot of distortions upon the material, but it is only the latter that will be the subject of interest in this essay. Ka-Spel has always seen his music and lyrics as inseparable, but fans and critics alike have long recognized that 
the lyrics could easily stand on their own, as they are nothing short of deeply imaginative poetry. This line of thought has been pursued most persistently by the San Francisco-based editor and publisher K. Janene-Nelson, whose painstaking care and effort finally translated Ka-Spel's lyrics into poetry proper in the shape of a beautifully illustrated and illuminated collection entitled Love and Loud Colours, published in 2002.

The rich visual aspect of the book, drawing on a vast array of sources from medieval Parisian calligraphy to Serbo-Cyrillic iconography, does not merely compensate for the absence of music, but rather proves that Edward Ka-Spel's words are equally at home in the textual-visual field as they are in the territory of the textual-audial. As such, Ka-Spel's poems display close affinities with the theories of, say, Carlo Belloli, who was convinced that "poetry was bound to escape from the pages of a book," who believed that the poet should be "a semantic architect systematically seeking a new space medium, an open site which is to be found neither in the library nor on the wall," and whose ultimate goal was "to fully represent the relationship of word, sound and visuality" (Solt). Moreover, if Ka-Spel often takes up the haunting sense of loss, so pronounced in the postmodern age, and turns it into a playful piece of writing, he is tapping into what Eugen Gomringer - an advocate, like Belloli, of "concrete poetry" - celebrates as a poem/object "made concrete through play-activity" (Gomringer). Since both Gomringer and Belloli are related with the postmodern of the aesthetic variety, i.e. with postmodernism as a continuation and further elaboration of high modernism, Ka-Spel's affinity with these figures clearly situates him on the same family tree.

It can be argued, though, that Ka-Spel's art is also postmodern in the sense of postmodernity, meaning that it operates from an all-pervasive network of plurality, fragmentation and repetitiveness - just some of the keywords of postmodernity, but all of them featuring quite heavily in his poetry. Equally, subjectivity is constantly undermined and split by Ka-Spel. His poems often feature a first-person voice or narrator, presumably Ka-Spel himself, but the identity of this subject is inherently unstable, free-floating and disjointed, roughly along the lines of Roland Barthes' discussion of the role of the writer: "The writer is always on the blind spot of systems, adrift; he is the joker in the pack, a mana, a zero degree, the dummy in the game: necessary to the meaning (battle), but himself deprived of fixed meaning" (Barthes 35). In fact, Ka-Spel's poems deconstruct the self so thoroughly that they invoke Michel Foucalt's definition of the self as "a complex and variable function of discourse" (Foucalt 138). Indeed, the labyrinthine character of Ka-Spel's writing would seem to lend a lot of credibility to another postmodern dictum formulated by Roland Barthes, regarding the relationship between textuality and subjectivity:

Whereas hitherto we have always taken this tissue as product, a ready-made veil, behind which lies, more or less hidden, meaning (truth), we are now emphasizing, in this tissue, the generative idea that the text is made, is worked out in a perpetual interweaving; lost in this tissue - this texture - the subject unmakes himself, like a spider dissolving in the constructive secretions of its web. (64) 
Yet, for all his affinities with the postmodern both in its aesthetic and philosophical guise, Ka-Spel's poems are also informed by conscious and unconscious longing for lost absolutes and certainties. The fragmented nature of his work might reflect the already-discussed "postmodern condition", but it also speaks of a heart-felt loss of totalizing and universal perspectives from which to study life or create art. Though celebrated by postmodern theory as a loss of something that never existed in the first place except as a world-shaping myth, the crack in human consciousness this loss has caused seems to be real enough to make it one of the main themes of Ka-Spel's poems.

Loss, confusion and longing for unity operate on many levels in Ka-Spel's poems, since his creative method is "the terminal kaleidoscope", a self-coined term for the idea that lends his words and music their outlandish, other-wordly feel; the idea that the ultimate reality beyond fragmentation and separation is one of unbound creative patterning of a unified field. The inner multiverse of the mind is what Ka-Spel paints in the brightest colours, and in the process "expresses the inexpressible", as his publisher puts it in Introduction to Love and Loud Colours (Ka-Spel IX). He pushes his themes to the limit, and from the cacophony of voices harvests pure joy - even in places where those voices suffer or break down.

A frequent motif, as has already been suggested, is that of the blending, or mingling - of disparate senses, identities, even religions. The result may not always be pleasurable, but the altered state of consciousness that accompanies this imaginative act nevertheless yields a fresh perspective, as in "Through your eyes I watched the red sun burst / and slowly melt into a dead sea / Through your senses I kissed dying time" (Ka-Spel, "Crushed Velvet" 5). In the same poem, we hear "the mountain laugh / the banshee cry, the statue of Mohammed roll the dice / to plastic Buddha, screaming 'Christ! Another six - / I guess it's time to pack my things, / head back slowly to Nirvana' " (5). Here, within no more than two verses, the reader encounters the head figures of three major global religions, all centred around the divine number six, as appearing on the face of a dice. In this rather predictable game, the number is always six, Buddha is a New-Age fake, Mohammed is a forbidden statue and Christ a mere turn of phrase. Yet, even in this truly postmodern, rather flat condition, something remains of the longing for that which transcends our alienation, as beautifully expressed in the poem's final line: "So it goes we stand alone by standing stones and turn them into circles." It is worth mentioning, perhaps, that the musical rendition of "Crushed Velvet" is built around an axis of discordant industrial noise, thus evoking early avant-garde experiments of Luigi Russolo, the Italian futurist who wrote that "we must break this restricted circle (sic!) of pure sounds and conquer the infinite variety of noise-sounds" (Lombardi).

Similar questioning of our cosmic abandonment appears in "Zero Zero", a kind of lament on the impossibility to solve basic ontological conundrums: "No doors deep inside this corridor of space and time / if space and time exist...” (Ka-Spel 6) The poem would seem to invoke Einstein's famous thought about God not playing dice, thus providing a fine echo of the previous poem, with its bored, dice-playing prophets. Einstein's general relativity, however, does not satisfy the ever-doubtful speaker, and nor does general rela- 
tivity's shadow twin quantum mechanics, since after "we tried splitting quarks", we still "need a sign - is anybody there? Are you listening?" (6). Interestingly, elsewhere, Ka-Spel expresses an optimistic belief, or rather the willingness to believe, "in the nobility of the human spirit." ("A Velvet Resurrection" 111) Here, he actually revisits the ontological questioning of "Zero Zero" by stating that "I want to believe mankind will never be too arrogant to / abandon its quest for an ultimate answer" and that "this ultimate answer remains a simple question". Quite what that question might be is not specified. After all, even the speaker finally admits that “you've caught me at a bad moment / and I can't" (111).

Both "Zero Zero" and "A Velvet Resurrection” also exemplify Ka-Spel's obsession with space, or rather spaces, which often appear to have the peculiar ability to entrap and enclose his speakers/characters in their very vastness and openness, very much like wide and open philosophical questions do. One such experience of being trapped in a lonely corner of the space-time continuum is related in "Hallway":

Shipwrecked in this gaping hole in time. In this lost museum that's forever closed inside. A place where nothing dies, it only crumbles. And I fumble. The statues turn their backs and just collapse in piles of ashes, remnants, fragments, ruins, trash. They torched this temple years ago, but they left the ghosts to moan on glowing coal - in a hall that leads to a hall - that leads to a hall - that leads to a hall... (89)

The prevalent atmosphere of doom and decay speaks through these images where things appear to only exist in the form of endless fragmentary copies of themselves, and thus, once again, in a postmodern condition where fragments and ruins are all that there is and where the seeming openness and freedom is but a "gaping hole in time". However, the unifying idea of the "terminal kaleidoscope" once again comes to the rescue, and the fragmentation and crumbling which looks so hopeless and desperate in "Hallway" does not appear as irredeemable in some of the other poems. For example, in "The Lovers, Part 2", fatal fragmentation and decay is portrayed as just one possible state of existence where "it only takes a push - china doll will fall apart" (143). Fortunately, a repositioning of the pieces in the terminal kaleidoscope may lead to an entirely different - and a lot more blissful - state of being in which "it only takes a touch - and china doll will start to dance". In the last line of this poem, as if faced by a Shakespearean question of "to be or not to be," the speaker takes a clear stance in the imperative: "Dance, china doll!" (143). Thus, the unification of fragments, the smoothing out of cracks is another frequent motif of Ka-Spel's imagery, and although it is often just desired rather than fully achieved, it remains one of the most tangible manifestations of the "terminal kaleidoscope" in Ka-Spel's poetry. Or, as he puts it himself in "With Wings": "The Crippled soul unites and prepares for the long journey home" (145).

Sometimes, though, the terminal kaleidoscope reshapes itself into an image totally inaccessible to ordinary human consciousness, where the language creaks and bends as it struggles to "express the inexpressible". This happens in "A Space Between", a poem allegedly based on Ka-Spel's near-death experience. Language has been lent to uses - in 
fables or allegories - where plants, animals or even inanimate objects are invested with human characteristics. Here, it is stretched even further, as if in order to capture an experience outside the limits of ordinary consciousness, the author is left with just one option - to anthropomorphize situations, to give personalities and feelings to a whole web of far-reaching, albeit short-lived circumstances. This is what the poem comes up with:

Billy was a car crash - all he ever knew was pain. Lived a milli-milli-milli-second; never born again. Though no one saw him coming, plenty witnessed his remains - laid a wreath, yet they never knew him. Me? I'm just the rain. Laid poor Billy to eternal rest, eternal rust. I soaked the dust that covers him, I wait for all the others. (They all have names.) (120)

A car crash called Billy is made to feel all the pain and loneliness of his grotesquely short existence. Consequently, the reader is invited to feel not just for the victims of the car crash but for the car crash itself. Nothing short of stepping outside the box of regular thinking or ordinary imagining will do in order to appreciate the lyrical power of such courageous images.

Yet things can become even more mind-boggling in Edward Ka-Spel's world. Replace a car crash with a plane crash and you will get "The Unlikely Event", a poem written months BEFORE, not after 9/11, and therefore hailed as one of Ka-Spel's most visionary moments. This time, his dark imaginings lead the reader to an aisle full of screaming passengers, whose lives are about to be sacrificed to the will of Allah. The narrator remains cool, though:

My neighbour sinks his head between his knees.

Plane's tilted forty-five degrees.

Outside it's freezing, though God knows, now I need a

drink. (144)

The speaker here seems to be dismissive of his own impending demise and drily focuses on the objective facts of the situation:

On channel nine the dotted line stops short

a mile away

from Dallas.

But we're on a roll, shall dig a hole so deep that

we'll strike oil.

Black gold, that Texas tea.

It's 3:15, I hear your voice mail.

Are you with your secret lover, Lover? (144)

There is something almost unbearably disturbing in the notion of a passenger flying towards his death while calling his wife to say goodbye and wish her good luck even if she is with her secret lover. On the part of the reader, it arguably requires the same leap of 
imagination as in the case of the previous poem. The passenger's act of selfless love in the face of death may bring him nothing short of redemption, while the author remains in full control of his art, alluring the reader into his fragmented world which every now and then reveals a magnificent whole. Where it does not, the yearning for unity itself remains the promise, as in "These fragments are glued to my sails. /... And I blew you a kiss / but I missed, / and you left me like this. I fade away, float away" ("Malice through the Looking Glass," 81). At other times, the fragmentation and flatness of existence appears irreversible and redemption too far out of hand. An afterlife might come in handy, but in some of Ka-Spel's poems, the post-mortal world feels closer to the spectral, shadowy underworld of the Egyptians or Greeks rather than the ecstatic paradise of Christianity or Islam. In fact, Ka-Spel turns the afterlife into a dystopian version of the here and now, where the robotic, the mechanic and the endlessly repetitive are the only reasonable shots at immortality:

\section{My robotic afterlife}

was tainted with rejection.

I'd gaze at my reflection and see rust.

Let's form a club for all the clones that never made it.

Techno lepers, cyber chumps, prosthetic paupers

plunging pliers in your pocket... (“Mekkanikk" 102)

The dystopian impulse, only hinted at in this poem, is fully unleashed in "New Tomorrow", a deeply unsettling vision of a Huxley-style brave new world, charming in its intoxicating beauty yet sinister because all-embracing:

And we have watched the sun roll down the mountain

to a frozen lake. We heard our laughs

go on forever

deep inside a crystal cave.

We told them as they plunged the needle,

pledging our escape

from the all-embracing arms of New Tomorrow -

We shall see our kingdom come! (84)

The final stanza of the poem contains all the motives typical of Ka-Spel's imagery: there is the oxymoronic rolling of the sun down to a frozen lake, the maddeningly repetitive laughter going on forever, and finally there is the religious incantation of the concluding line. Ka-Spel is not easily deceived by the showy colours and the fireworks of "New Tomorrow" and would actually prefer a spell of cloudy weather, as in "Waiting for the Cloud" where "the river was a rainbow stew / the fishes choked and cursed. / We saw it all in colour / now we're waiting for the cloud" (44). Here the dystopian meets the environmental, in a special kaleidoscopic constellation enabled by Ka-Spel's particular sensitivity unafraid of the wildest ranges of imagination. In fact, Ka-Spel insists that a careful rearrangement of perception might enable us to cut a radically different route through 
the evolutionary maze, a route which might summon the best, rather than the worst of humanity:

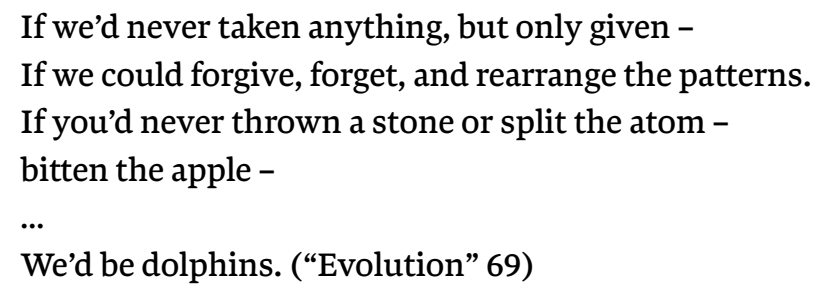

The passage might well have been written by Theodor W. Adorno, but unlike him, Ka-Spel actually still believes that poetry is possible. In a postmodern age where transcendence has been flattened out into a consumerist marketplace, Ka-Spel invites the reader to re-expand themselves through the power of imagination and love. Since for all the desperate fragmentation and "this hollowed ground" of contemporary life, "we shall push and we shall pull and we shall rise / above it all / We shall fly above it all" ("This Hollowed Ground" 47).

The poems from Love and Loud Colours that arguably best encapsulate Ka-Spel's problematic and therefore creative relationship with the postmodern are those written as short prose. When set to music, these epic pieces are almost always delivered as a dramatic monologue gradually drowned in a river of psychedelic noise. These pieces are, once again, fragmentary in nature, and tend to contain all Ka-Spel's trademark themes and motives. Examples of such prosaic pieces include the already discussed "Hallway" or "A Velvet Resurrection", but the one piece that truly captures the essence of Ka-Spel's imagery is undoubtedly "Godless," which can be found roughly half-way through the collection. The poem starts, somewhat typically for Ka-Spel, in an empty apartment that quickly turns into something resembling an inescapable prison cell: "First of all the room vibrated. Then there was a second wave, more intense. Pictures fell from the wall... A crack appeared in the ceiling" (80). So here it is - a narrator caught in what seems to be an earthquake, his room cracking and falling like the House of Usher, yet preserving his keen eye for detail and time-keeping: "Flakes of plaster piled up on the carpet. It was a new carpet. The lights went out. After eighteen minutes the first wall collapsed; I was not injured" (80). The survival instinct obviously urges the narrator to crawl out of the room, but he soon realizes that life's big questions are not always answered by what one is escaping from but rather what one is escaping to: "I decided to crawl through the debris to get outside. There was nothing outside." Engulfed by overpowering nothingness, he comes to the realization that he is "a fragment, detached from time and space. Forgotten, rejected" (80). The hopeless fragmentation and meaninglessness of existence is all the narrator finds outside the doors of his collapsed dwelling. In other words, he finds his own postmodern condition. The task now is to bridge this depthless abyss - by contact, by love, by transcendence: "A face desperate for a name, but finding none. Always on the point of recognition, hovering above an answer, but not finding one. Thirsty for contact, but finding none" (80). Entrapped in an endless repetition of the same, the narrator nev- 
ertheless keeps searching, questioning, trying to transcend his alienation by a simple act of human contact and communication. In this way, the poem keeps the hope and promise alive and the question "Were you ever there?" does not ring hollow in "a nothing that goes on forever" (80).

Edward Ka-Spel, an experimental artist equally linked to postmodernism (in his kaleidoscopic musical and lyrical interventions) and postmodernity (particularly in his choice of themes), shows us that well into the twenty-first century, and in spite of postmodernity claiming otherwise, "life has a meaning, you know" (147). Both musically and lyrically, Ka-Spel combines various forms of poetic experimentation, associated with the 20th-century avant-garde, in surprising, novel ways, and thus proves that "the postmodern condition" in which we live, far from being a hindrance to poetry, can actually be one of its powerful engines.

\section{[Bibliography]}

Barthes, Roland. The Pleasures of the Text. London: Jonathan Cape, 1976.

Baudrillard, Jean. “Game with Vestiges.” On the Beach 5 (Fall 1984): 19-25.

Foucalt, Michel. Language, Counter-Memory, Practice. Ithaca: Cornell University, 1977.

Gomringer, Eugen. From Line to Constellation. Web. 7 July 2019. <http://www.ubu.com/

papers/gomringer01.html>

Jameson, Fredric. Postmodernism or the Cultural Logic of Late Capitalism. London: Verso, 1991.

Ka-Spel, Edward. Love and Loud Colours. San Francisco: Saint Rapunza, 2002. <https:// legendarypinkdots.org/>

Lombardi, Daniele. Futurism and Musical Notes. Web. 5 July 2019. <https://www.ubu.com/ papers/lombardi.html>

Lyotard, Jean-François. Just Gaming. Minneapolis: University of Minnesota, 1985.

Solt, Mary Ellen. Italy. Web. 5 July 2019. <https://www.ubu.com/papers/solt/italy.html>

\section{[Address]}

Silesian University in Opava

Faculty of Philosophy and Science

Institute of Foreign Languages

Masarykova tr. 37

74601 Opava

Czech Republic

radek.glabazna@fpf.slu.cz

Radek Glabazña teaches English literature at the Institute of Foreign Languages, Silesian University in Opava, Czech Republic. His research interests include postcolonial theory, theories of the postmodern 
and the relationship between contemporary poetry and music. He is also a creative writer who has published two collections of verse: It only takes splinters in the head (Perplex 2010) and Reverb (Perplex 2017). Most recently, his interests in general theories of education led him to translate Maria Montessori's book The Absorbent Mind (Portál 2018). 